\title{
Food Ethics in Ancient China: A Confucian Perspective
}

\author{
Chun-chieh HUANG*
}

\section{Introduction}

Food ethics in ancient China was a complex of ideas that emerged from the Chinese view of life and attitude toward the elderly. They can be seen as the manifestation of the Confucian political ideal of the "kingly way," and in particular, the related idea of "humane governance." Food ethics in ancient China was also linked to the everyday practice of eating, especially in the context of rural life. In this paper, I will attempt to parse this thesis, focusing on Mencius' saying that "those who are seventy can eat meat."

In his conversation with King Hui of Liang (梁惠王, r.319-301 BCE), Mencius (孟子, 372-289 BCE) expounded his ideal of the "kingly way" of governance. He stated: ${ }^{1}$

If the mulberry is planted in every homestead of five $m u$ of land, then those who are fifty can wear silk; if chickens, pigs and dogs do not miss their breeding season, then those who are seventy can eat meat; if each lot of a hundred $m u$ is not deprived of labour during the busy seasons, then families with several mouths to feed will not go hungry. Exercise due care over the education provided by the village schools, and discipline the people by teaching them the duties proper to sons and younger brothers, and those whose heads have turned hoary will not be carrying loads on the roads. When those who are seventy wear silk and eat meat and the masses are neither cold nor hungry, it is impossible for their prince not to be a true King.

* Chun-chieh HUANG 黄俊傑 is distinguished chair professor of National Taiwan University and President of Wen-de Academy

1 D. C. Lau trans., Mencius (Hong Kong: The Chinese University Press, 1984), Bk.1, Part A, Chap.3, p.7. 
五㛤之宅，樹之以桑，五十者可以衣帛矣; 雞豚狗荍之畜，無失其時，七十者 可以食肉矣; 百畧之田, 勿奪其時, 數口之家可以無飢矣; 謹庠序之教, 申之以 孝悌之養，頒白者不負載於道路矣。七十者衣帛食肉，黎民不飢不寒，然而不 王者，未之有也。

In Mencius' political thought, this scenario represents the ideal state. In his conversation with King Xuan of Ci (齊宣王, r.319-301 BCE), Mencius stressed this ideal again.

Mencius placed the idea that "those who are seventy can eat meat" at the heart of his theory of ideal governance. What is the significance of the notion that "those who are seventy" are eligible to "eat meat"? The commentators on the Mencius, Zhao Qi (趙岐, 108-201) of the Later Han (25-220 AD), Zhu Xi (朱喜, 1130-1200) of the Southern Song (1127-1279), and Jiao Xun (焦循, 1763-1820) of the Qing Dynasty (1644-1912) said that if seventy-year-olds do not eat meat, they might experience hunger. This explanation, however, does not go far enough. In fact, Mencius' doctrine was deeply imbued with the spirit of honoring the elderly and the everyday practice of eating. As such, Mencius concretized food ethics in ancient China.

\section{Views on Age and Respect for the Elderly in Ancient China}

Our discussion of food ethics in ancient China began with Mencius' maxim that "those who are seventy can eat meat." According to traditional Chinese thought as inscribed in the ancient classics, a person's life can be broken down into a series of ten-year stages. The Book of Rites states: ${ }^{2}$

When one is ten years old, we call him a boy; he goes (out) to school. When he is twenty, we call him a youth; he is capped. When he is thirty, we say, 'He is at his maturity;' he has a wife. When he is forty, we say, 'He is in his vigour;' he is employed in office. When he is fifty, we say, 'He is getting grey;' he can discharge all the duties of an officer. When he is sixty, we say, 'He is getting old;' he gives directions and instructions. When he is seventy, we say, 'He is old;' he delegates his duties to others. At eighty or ninety, we say of him, 'He is very old.' When he is seven, we say that he is an object of pitying love. Such a child and one who is very old, though they may be chargeable with crime, are not subjected to punishment. At a hundred, he is called a centenarian, and has to be fed.

2 James Legge trans., Li Chi: Book of Rites (Montana: Kessinger Publishing, 2003), vol.1, "Khü Li," pp.65-66. 
人生十年曰幼, 學; 二十曰弱, 冠; 三十曰壯, 有室; 四十曰強, 而仕;五十曰艾, 服官政; 六十曰者, 指使; 七十曰老, 而傳; 八十九十曰老; 七年曰悼。悼與老, 雖 有罪，不加刑焉。百年曰期，願。

According to this passage, when a person reaches the age of seventy, he or she is regarded as "old" and should retire from social activities. Elsewhere, the Book of Rites states: "A great officer, when he is seventy, should resign (his charge of) affairs. If he be not allowed to resign, there must be given him a stool and staff." 3

The same text also states that:

At forty, he was first appointed to office; and according to the business of it brought out his plans and communicated his thoughts. If the ways (which he proposed) were suitable, he followed them out; if they were not, he abandoned them. At fifty, he was appointed a Great officer, and laboured in the administration of his department. At seventy, he retired from his duties. ${ }^{4}$

As was commonly practiced in ancient China, a man began rendering government service at the age of forty, and retired at the age of seventy.

When a man reached the age of seventy, he would receive great respect. According to the Discourses of the States, Duke Dao of Jin (晉悼公, r.572-558 $\mathrm{BCE}$ ) in the Spring and Autumn period (722-481 BCE) received guests older than seventy. ${ }^{5} \mathrm{~A}$ minister suggested that the king consult seniors regarding major affairs of state. ${ }^{6}$ In ancient China, feudal lords often sought advice from people aged seventy or older.

In ancient China, a person was considered elderly at the age of fifty, and would thereafter be honored and nurtured, as was sanctioned in the ancient texts. The Book of Rites states that:

In nourishing the age, $[\ldots . .$.$] For those of fifty, the grain was (fine and)$ different (from that used by younger men). For those of sixty, there was meat kept in store (from the day before). For those seventy, there was a second service of savory meat. ${ }^{7}$

3 Ibid., p.66.

4 James Legge trans., Li Chi: Book of Rites, vol.1, "the Nei Zeh," p.479.

5 “Jinyu” 晉語 [Discourses of Jin], in Guoyu 國語 [Discourses of the States] (Sibu Congkan chubian suoben edition 四部叢刊初編縮本), vol.13, pp.100-101.

6 "Jinyu," in Guoyu, vol.14, p.106.

7 James Legge trans., Li Chi: Book of Rites, vol.1, "the Nei Zeh," p.465. 
One reason for the special reverence accorded to seventy-year-olds was the relatively short life expectancy in ancient China (due mainly to the material conditions of everyday life and food scarcity). Seventy-year-olds were called "old people" and did not take part in the government business of defence or planning. ${ }^{8}$ In Former Han times, at the age of eighty a man was called a t'ieh 耊, while at the age of seventy he was a mao 老. A septuagenarian could not feel full without meat or warm without silk. ${ }^{9}$ This was in line with Mencius' description, "those who are seventy wear silk and eat meat," and further embodies food ethics in ancient China.

In ancient China, food ethics was intrinsically linked to age, which was used to measure a person's spiritual journey through life. Confucius said, "To be neither modest nor deferential when young, to have passed on nothing worthwhile when grown up, and to refuse to die when old, that is what I call a pest." (Analects, 14.43) ${ }^{10}$ In his own reflections upon his spiritual transformation, Confucius asserted that he reached the highest point at the age of seventy. This is consistent with the fact that those who were seventy were called septuagenarians in ancient China. ${ }^{11}$

\section{Eating in Ancient Chinese Society}

The ethical ideas about food inherent in Mencius' statement that "those who are seventy can eat meat" pertain to the everyday practice of eating in ancient China. As Kuang-chih Chang (張光直) argues, the raw materials for preparing food in ancient China were complex and diverse. Rice ( fan 飯) and food ( $c a i$ 菜) belonged to different categories - a distinction based on ideas of health, medication, and nutrition. Furthermore, the major customs and ideas about eating in Chinese culture remained virtually unchanged for three thousand years. ${ }^{12}$ Importantly, meat was not considered essential and was regarded as a luxury. Coarse rice and water, on the other hand, were fundamental and indispensable. Beyond basic rice, one might eat meat after first consuming vegetables. ${ }^{13}$ In ancient China, members of different social classes, such as

8 Ian Johnston trans., The Mozi: A Complete Translation (New York: Columbia University Press, 2010), Bk.70, Chap.6, pp.860-861.

9 Esson M. Gale trans., Discourses on Salt and Iron (Taipei: Ch'eng-wen Publishing Company, 1967), chap.25, pp.189-190.

10 D. C. Lau trans., The Analects (Hong Kong: The Chinese University Press, 2000), Bk.14, chap.43, p.147.

11 D. C. Lau trans., The Analects, Bk.2, chap.4, p.11.

12 K. C. Chang ed., Food in Chinese Culture: Anthropological and Historical Perspectives (New Haven: Yale University Press, 1977), p.14.

13 Chang Kuang-chi 張光直, “Zhongguo gudai de yinshi yu yinshiju” 中國古代的飲食與 飲食具 [Drinking, Eating, and Utensils], in his Zhongguo qingtong shidai 中國青銅時 代 [Bronze Age of China] (Taipei: Lianjing chuban shiye gongsi, 1983), pp.249-283, 
commoners, scholar-officials, and feudal lords, ate different kinds and qualities of food. ${ }^{14}$ Archeological evidence suggests that the nobility in ancient China ate a variety of meats, including pork, lamb, beef, dog, horse, rabbit, chicken, duck, bird, and pheasant. ${ }^{15}$ Generally, however, people consumed far more rice than meat in ancient China. ${ }^{16}$

In ancient China, common people consumed very simple food. The Book of Odes states: ${ }^{17}$

In the sixth month they eat the sparrow-plums and grapes;

In the seventh, they cook sunflower seeds and beans;

In the eighth, they knock down the dates;

In the tenth, they reap the rice

And make the spirits for the spring

For the benefit of the bushy eyebrows.

In the seventh month, they eat the melons;

In the eighth, they cut down the bottle-gourds;

In the ninth, they gather the hemp-seed;

They gather the sow thistle and make firewood of the ailanthus tree

To feed our husbandmen.

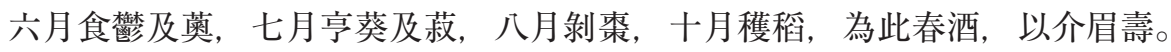

七月食瓜，八月斷壶，九月叔苴。采茶薪橒，食我農夫。

This poem vividly depicts the lives of farmers in ancient China. Their food included grapes, sunflower seeds, beans, melons, and sow thistle. The philosopher Mozi (墨子, 479-381 BCE) reported that "in the times when the people of old still did not know how to make drink or food, they ate simply and lived separately."18 To eat "simply" here refers to eating vegetables. Mozi

esp. p.274.

14 Shi Shuqing 史樹青, “Tan “yinshi kaogu”” 談「飲食考古」[Some Notes on the Archeology of Food], in Kaogu yu wenwu 考古與文物 [Archeology and Documents], 6 (1984): p.103.

15 Yang Aiguo 楊愛國, “Han huaxiangshi zhong de paochutu” 漢畫像石中的庖廚圖 [Pictures of Kitchens in the Stone Paintings of the Han Dynasty], in Kaogu 考古 [Archaeology], 11(1991): pp.1023-1031, esp. p.1028.

16 Min Zongdian 閔宗殿, “Woguo yinshi jiego de huigu yu sikao” 我國飲食結構的回顧 與思考 [Food Structure in China: Retrospection and Thinking], in Zhongguo nongshi 中國農史 [Chinese Agricultural History], 2 (1991): pp.59-66.

17 James Legge trans., “Ts'ih Yueh" 七月, The Odes of Pin 疄風 in The Chinese Classics (Taipei: SMC Publishing Inc., 1991), vol.4, Bk.15, pp.226-233.

18 Sun Yirang 孫詒讓, Mozi xiangu 墨子閒詁 [Commentaries on the Mozi] (Beijing: Zhonghua shuju, 1986), Bk.6, p.35. 
also reports that people ate fruits and melons in summer and vegetables and grains in autumn, ${ }^{19}$ and affirms that the five grains were the staple for most people. ${ }^{20}$ This style of eating emerged as early as Han times. ${ }^{21}$ It was also in the Han period that the five grains came to be regarded as medication. ${ }^{22}$

In ancient Chinese society, commoners ate simple food. Confucius once praised his pupil, Yan Hui (顏回, 521-481 BCE), for living in a mean dwelling and surviving on only a bowlful of rice and a ladleful of water. ${ }^{23}$ In the fourth century BCE, Mencius encouraged feudal lords to put humane governance into practice by reminding them that "your army is met by the people bringing baskets of rice and bottles of drink." 24 All these records attest to the simplicity of the food of common people in ancient China. Soup and boiled grain were consumed everyday by people of all social classes, ${ }^{25}$ but common people would only eat meat on special festival days. ${ }^{26}$

In sum, for most people in ancient China, meat was hard to come by. The "flesh-eaters" were those of the ruling class. ${ }^{27}$

\section{An Explanation of Food Ethics in Ancient China}

As viewed in a global context, the food ethics as articulated by Mencius and Confucians are unique to ancient China. Anthropologists have documented various kinds of "death-hastening behavior" directed towards the elderly in non-industrial societies around the world, including killing and abandonment. ${ }^{28}$ For example, in Polar Inughuit society, the aged are left

19 John S. Major et. al. trans., The Huainanzi (New York: Columbia University Press, 2010), Bk.9 "The Rulers' Techniques," Chapt.28, pp.330-331.

20 Ian Johnston trans., The Mozi: A Complete Translation (New York: Columbia University Press, 2010), Bk.5, Chap.2, p.31.

21 Huang Zhanyue 黃展岳, “Handai ren de yinshi shenghuo" 漢代人的飲食生活 [Food of People in the Han Dynasty], in Nongye kaogu 農業考古 [Agricultural Archeology], 1(1982): pp.71-80.

22 See Cheng Jianhua 程劍華, “Gudai nongye yu zuguo yixue de shiwu liaofa” 古代農 業與祖國醫學的食物療法 [Ancient Agriculture and Food Medication in Chinese Medicine], in Nongye kaogu, 2(1984): pp.370-380.

23 D. C. Lau trans., The Analects, Bk.6, chap.11, p.49.

24 D. C. Lau trans., Mencius, Bk.1, Part B, chap.10, p.41.

25 James Legge trans., Li Chi: Book of Rites, vol.1, p.464.

26 Ma Feibai 馬非百, “Xianbuzu 29” 散不足第二十九, Yentie lun jianzhu 鹽鐵論簡注 [Commentaries on the Discourses on Salt and Iron] (Beijing: Zhonghua shuju, 1984), p.229. Cf. Li Shaochiang 李紹強, “Zhongguo gudai de jieri yinshi” 中國古代 的節日飲食 [Food in Ancient Chinese Festivals], in Zhongguo nongshi 中國農史 [Chinese Agricultural History], 1(1990): pp.105- 110.

27 James Legge trans., The Chinese Classics, vol.5, Tso Chuen, Duke of Chwang, $10^{\text {th }}$ year, p.86 and p.832.

28 Jay Sokolovsky ed., The Cultural Context of Aging: Worldwide Perspective (Westport, Conn.: Bergin and Garvey, 1997), p.62. 
behind to fend for themselves or perish. 29 Similarly, the Witotos of Northwestern Amazonia remove the aged and the infirm from society and leave them in the bush to die. ${ }^{30}$

Some of the characters inscribed on the oracle bones used for divination in Bronze Age China have been identified as depicting the killing of the elderly. ${ }^{31}$ This sort of behavior can be traced back to the Paleolithic Age. It was also a common practice in ancient China to leave the elderly in the mountains to be eaten by beasts. ${ }^{32}$ Moreover, those over sixty were sometimes buried alive in ancient China. ${ }^{33}$

Against this historical background, two possible explanations for Confucian food ethics may be offered. Firstly, in the days of Confucius, Mencius, and the Former Han Dynasty (25-220), when the Book of Rites was composed, China was an agrarian society where food and other resources were not as scarce as they had been in the Shang dynasty (c.1600 BC-c.1046 $\mathrm{BC})$, during which nomadic societies dominated.

Among the many nomadic peoples who interacted with the Han Chinese people throughout Chinese history, the Huns played an important role in the development of the Han Dynasty (206 BCE-220 CE). Historians have concluded that in the nomadic society of the Huns, the young and the strong ate the best food while the elderly ate the food that remained. ${ }^{34}$ A possible explanation for this is that nomadic societies frequently suffered from food shortages and the elderly might become a burden for the tribe. Unlike the nomadic society of the Huns, Han dynasty China - the China of Confucius and Mencius - was a mature agrarian society in which "death-hastening behavior" would be regarded as immoral.

Moreover, in agrarian societies such as ancient China, experience-based knowledge was highly esteemed. The elderly had more experience, and therefore more knowledge, of farming than young people. Among the many

29 George Peter Murdock, Our Primitive Contemporaries (New York: The Macmillan Co., 1934), p.214.

30 Ibid., p.467.

31 Xu Jinxiong 許進雄, Zhongguo gudai shehui: wenzi yu renleixue de toushi 中國古代 社會:文字與人類學的透視 [Ancient Chinese Society: An Epigraphic and Archaeological Interpretation] (Taipei: Taiwan shangwu yinshuguan, 1988), p.434.

32 Ibid., p.436.

33 Ma Changshou 馬長壽, “Zhongguo gudai huajia shengzang zhi chiyuan yu zaixian" 中國古代花甲生藏之起源與再現 [On the Origin and Reemergence of Live Burial at the Age of Sixty], in Zhou Weizhou 周偉洲 ed., Ma Changshou minzuxue lunji 馬長 壽民族學論集 [Collection of Essays on Ethnology by Ma Changshou] (Beijing: Renmin chubanshe, 2003), pp.14-45.

34 See Ban Gu 班固, Han shu 漢書 [History of Han] (Beijing: Zhonghua shuju, 1964), p.3743. 
schools of thought in ancient China, Confucianism was distinctly historicallyminded. ${ }^{35}$ It was therefore natural for Confucians, and most notably Mencius, to articulate food ethics that favored the elderly.

\section{Conclusion}

In this paper, I have contextualized Mencius' expression that "those who are seventy can eat meat" in relation to food ethics and eating practices in ancient China. A person would retire from public service at the age of seventy and would subsequently receive respect from other members of society, especially if his self-cultivation had progressed with age.

Moreover, common people in ancient China suffered from a scarcity of material resources, including food. Most meals, therefore, consisted of rice and vegetables. Only on special festival days were common people able to eat meat. This was the reason Mencius regarded the provision of meat for those aged seventy and over as a hallmark of humane governance. Confucian food ethics, therefore, grew out of the everyday practices of agrarian society, as well as Confucianism's profound philosophical commitment to history and age.

35 Chun-chieh Huang, Humanism in East Asian Confucian Contexts (Bielefeld: Transcript Verlag, 2010), p.25. 